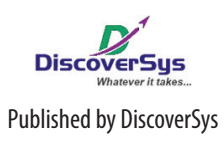

Published by DiscoverSys

\section{The role of communication contact in capitation implementation at public health centres in Denpasar}

\author{
Ni Putu Purlimaningsih, ${ }^{1 *}$ I Ketut Suarjana, ${ }^{2,3}$ Pande Putu Januraga ${ }^{2,3}$
}

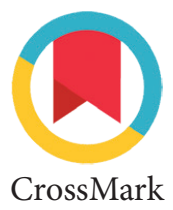

CrossMark

\section{ABSTRACT}

Background and purpose: One of the main indicators of quality in the provision of primary health care is the contact between the provider and the recipient (communication contact). Targets set regarding communication contacts are often not achieved which in turn results in consequent cuts in the capitation rates received by the public health centres (PHCs). The purpose of this research is to understand the implementation, inhibiting and enabling factors of supporting communication contact in the era of National Health Insurance (Jaminan Kesehatan Nasional/JKN).

Methods: This study used a qualitative explorative design through indepth interviews and focus group discussion (FGD) with 22 informants consisting of heads of PHCs, PHCs staff, Head of Denpasar Health Office, Head of Social Security Administering Agency (BPJS) Denpasar Branch and JKN members. This research was conducted at 11 PHCs in Denpasar City from April to July 2017. The informants were chosen purposively and the data were analysed thematically to explore aspects of implementation, the inhibiting and enabling factors of communication contact.
Results: Communication contacts can be assessed both inside and outside the PHCs buildings. The inhibiting factor of communication contact implementation related to difference in understanding of the concept of PHCs working area, the absence of a standard operational procedure (SOP) for communication contact, heavy workload of PHCs service providers, lack of optimal means of supporting application of pcare convoluted and confusing information from BPJS, and lack of understanding from JKN enrolees on the particulars of the administration and desire for speedy service. Supporting factors are the availability of media, training and orientation for the implementing staff and the feedback from BPJS to PHCs staff. Driving factors are the effective authority of the PHCs head, commitment and motivation from government agencies and cross-sectoral support.

Conclusions: Implementation of communication contact is influenced by both inhibiting and enabling factors, from the BPJS stakeholders and the members of the BPJS. Achieving the target of communication contact requires synergy of central government policy and BPJS managers.
${ }^{1}$ Kuta Utara Public Health Center, ${ }^{2}$ Public Health Postgraduate Program Udayana University, ${ }^{3}$ School of Public Health Faculty of Medicine Udayana University

${ }^{*}$ Correspondence to:

Ni Putu Purlimaningsih, Kuta Utara Public Health Center

purlimaningsihputu@gmail.com

Keywords: implementation, communication contact, commitment, capitation, service.

Cite This Article: Purlimaningsih, N.P., Suarjana, I.K., Januraga, P.P. 2017. The role of communication contact in capitation implementation at public health centres in Denpasar. Public Health and Preventive Medicine Archive 5(2): 152-157. D0I:10.15562/phpma.v5i2.31

\section{INTRODUCTION}

The provision of health services within the national health insurance system (SJSN) includes the social protection of participants by providing health care benefits addressing their basic health needs. This health insurance has been organized by the Social Security Administering Agency (BPJS) since January $1,2014 .{ }^{1}$ PHCs function as a primary care health facility (FKTP) conducting community health efforts (UKM) and individual health efforts (UKP) that are observational, preventive, promotive, non-specialist, diagnostic, and include care and treatment and other health services. ${ }^{2}$ BPJS has developed a payment system determined by capitation rate wherein BPJS compensates the FKTP reflective of service commitment. The tariffs applied are assessed through three indicators, namely the number of communication contacts, specialistic reference ratios and the number of routine chronic disease management service (prolanis) visits. The number of communication contacts is the total number of registered participants in any given
FKTP in contact with FKTP compared to the total number of participants registered at a FKTP multiplied by one thousand. ${ }^{2}$

JKN capitation funds distributed to PHCs should further optimize promotive and preventive services as it allows for more flexibility in developing these initiatives. FKTP staff are largely aware of the basic determination of capitation norms to assess capitation funds and view these as not sufficient to cover all health services for JKN participants. ${ }^{3}$

Implementation of capitation payments based on capitation norms and capitation-based service commitments (KBKP) has been rolled out in PHCs in Denpasar since January 2016. Within 11 PHCs implementing KBKP, a capitation cut of $2 \%$ to $5 \%$ has occurred. Of the 3 indicators established, the indicator of the communication contact appears to be the most impactful. ${ }^{4}$

Capitation cuts result in a decrease in service and facility funding revenues. Sixty percent of capitation funds are allocated for human resource 
overheads and $40 \%$ are used for operational expenditure, purchase of consumables, medical devices and medicines, among others. ${ }^{5}$ The purpose of this study is to obtain information on implementation, and to understand inhibiting/enabling factors regarding communication contact support in the JKN era. The results of this study are expected to be beneficial for informing policies and strategic plans ensuring the implementation of a more comprehensive and sustainable JKN.

\section{METHODS}

Study adopted an explorative qualitative approach to understand the implementation, and the enabling and inhibiting factors of communication contact support. This study was conducted from April to July 2017. The data was collected by in-depth interviews and FGDs involving 22 informants consisting of 5 heads of PHCs, 10 PHCs staff, 1 head of Denpasar Health Office, 1 head of BPJS Denpasar Branch and 5 JKN members. The informants were chosen purposively based on ranking from the highest, middle and lowest achievement of the target of communication contact. FGD participants were selected based on the nomination from the PHCs heads. The JKN informants were selected taking into account the knowledge and capabilities of the participants. The results were analysed by thematically starting with code identification and continuing with theme identification. The study protocol has been approved by Human Research Ethics Committee of Faculty of Medicine Udayana University/Sanglah General Hospital.

\section{RESULTS AND DISCUSSION}

Based on the analysis, the results of the research are presented in the form of themes, namely the implementation of the communication contacts, the inhibiting factors, the enabling factors and the driving factors in terms of communication categories, bureaucratic structures, disposition and resources.

\section{Implementation of communication contacts}

Implementation of communication contacts at health centres in Denpasar occurs both inside and outside of the health centre building. The following is an excerpt of an interview with a PHC head and one of the FGD participants on the building's activities.

"Everything is carried out, for example, immunisation, nutrition, assisting of both health and sick individuals". (Informant: K02).
"...We have contact with both sick and well patients, the sick are treated at the PHCs,... for healthy patients this includes services for pregnant women, nutrition assistance etc.... (Informant: K05).

"Inside the building people are attended to individually..." (FGD: F01).

In-building activities are individual contact activities when JKN participants come to the PHCs to utilise existing services, regardless of being well or sick. The results of the analysis indicate that some of the internal activities include immunisation services, nutrition, care for pregnant women and an extensive list of services for both sick and healthy participants. The activities within the building are focused on treatment for the individual (UKP). The following is an excerpt from an interview with a PHC head and one of the FGD participants on external work carried out.

"... outside of the PHC we conduct home care, information sessions, screening and early child care health services.... (Informant K05).

"...outside we work on maternal and child health support services, information sessions..." (FGD: F01).

External work includes activities undertaken by service providers in order to bring available services closer to the target (community). Services that support communication contacts in the form of outdoor activities includes home care, counselling, screening, healthcare for school age children, early illness detection and counselling. Outside activities are more community health related work.

The prescriptive portfolio of services conducted inevitably means that the PHCs head is unable to be flexible when making decisions regarding the implementation of BPJS health policies. ${ }^{6}$ The implementation of the communication contact is influenced by the role of the PHCs head in determining the type of service and the direction of the policy being implemented.

\section{Factors inhibiting the implementation of communication contacts}

Those responsible for communication contacts at PHCs demonstrate conflicted understandings of the implementation of Permenkes Number 75 Year 2014 between the Ministry of Health with BPJS Health No. HK.03/2016, No.01 of 2016 on the Implementation and Monitoring of the Application of Capacity-Based Compliance Commitment of 
Service at Primary Care Health Facilities. ${ }^{7,8}$ Here is an excerpt of an interview with one of the heads of a PHC.

"...If we are only compensated for the patients we directly serve that is not fair and not in the spirit of PERMENKES 75, as if when we conduct public dissemination sessions within the community, as if we will only assist those who are identified as direct beneficiaries...." (Informant: K04).

The results of the analysis indicate that the implementers at the PHCs understand two core concepts, namely the concept of health service delivery according to regional responsibility and the concept of prioritising contact with registered individual participants. The implementation of social security must be integrated and not partial. This reality impacts negatively upon quality of communication contacts.

Policymakers and administrators need to make considerations about the impacts and benefits of policies. ${ }^{9}$ One mechanism for controlling policy implementation is by evaluating the effectiveness of the communication contact policy. BPJS stakeholders should conduct an evaluation review on the process and performance of the communication contact policy.

PHCs can run efficiently in the instance there is good management in terms of service performance, service process and resources used. ${ }^{10}$ Efforts to clarify the roles and functions of each unit requires an SOP as a guide on the process of achieving the target of communication contact. The following statements from one of the PHCs heads and one of the FGD participants on the existence of communications SOPs reflect this.

“...There is no SOP...." (Informant: K02).

"...there is no standardised SOP...." (Informant: F01).

Study findings analysis indicate that not all PHCs have SOP about the implementation of communication contacts. Communication contact activities are an integration of UKP services and SME programs. The unavailability of communication SOPs as guidance in determining the steps of implementation of communication contact activities impacts upon the ability to roll out such initiatives effectively. Quality human resources are needed for the effective implementation of communication contacts. The following excerpts from one of the heads of the PHC and the head of the Health Service Division of the Denpasar Health Office reflects this:
"...If we talk about human resources, including the time and complexity of issues we need to deal with at the PHCs, clearly we do not just deal with JKN concerns..." (Informant: K01).

"... We have many issues to deal with and a heavy work load, we do not just need to consider these issues...." (Informant: D01).

It is evident that staff numbers are not comparable with the division of duties including those duties connected to capitation. The quality of communication contacts is not only determined by the monitoring from executive staff but these must be supported by ancillary facilities. The following is a statement from one of the heads of PHCs relating to the availability of pcare support facilities:

"The wif here regularly shuts down or is very slow...there are no reminders in pcare so we don't know whether we need to input data once or twice...." (Informant: K04).

Internet connections that support communication contacts are available in every PHCs however these often experience system failure or very slow connection, and inhibits the process of data input to pcare. The absence of a system of reminders in pcare regarding the number of times to input patient data impedes efficiency. The self-contained management of targeted contact communications interactions should be supported by ancillary resources and efficacious management. ${ }^{11}$ PHCs functioning as a work unit within the government should adopt the recommended financial management system framework which would enable them to be more flexible in the management of finances and allocates funds for improving the quality of service.

Barriers to the effective implementation of communications contacts also come from BPJS as the implementing partner of JKN. The following FGD excerpts reflect the unclear and inconsistent responses from BPJS when providing information to the implementers.

“...BPJS never gives us adequate guidance on data input..." (FGD: F04).

"...policy regularly changes without appropriate information..." (FGD: F04).

It is evident that information conveyed is unclear and inconsistent about the objectives and targets of a policy which potentially leads to resistance and possible lack of cooperation from the target group. ${ }^{12}$ Consistent implementation 
of policies guided by applicable procedures and norms will produce more positive results. ${ }^{13}$ Unclear and confusing information and lack of frameworks inevitably impacts upon the implementers willingness to comply and carry out the promoted policy.

JKN participants who utilise PHCs services do not fully understand their obligation to complete administrative requirements before access to services. The following is an excerpt from an interview with one of the heads of PHC regarding the frequent lack of compliance from JKN enrolees, particularly regarding displaying membership cards at time of presenting at clinic.

"...It also slows things down when they forget to bring their cards..." (Informant: K04).

JKN participants who do not carry JKN card on their person make it difficult for PHCs officers to perform the data input process. JKN members also mention that the lengthy administration processes when accessing health services is tiresome and laborious:

“... They really need to speed up the process..." (Informant: P02).

The results of the analysis indicate that JKN beneficiaries expect speedy service. This could be addressed by PHCs staff by improving the queuing system. ${ }^{14}$ Slow administration processes effectively limit the amount of time doctors and other implementing officers have to provide education about the diseases identified or conditions found. Research on the impact of JKN's policy on health promotion programs at PHCs indicates that JKN programs have a positive impact on the number of health promotion activities run after the release of funds coming from the capitation of JKN at PHCs. ${ }^{15}$ This is in contradiction to the expectation of patients who demand speedy service. Limiting the time doctors and officers are allocated for providing education is an inhibiting factor for communication contact.

\section{Enabling factors of communication contact implementation}

The results of the analysis indicate that the media used by the PHCs to convey information about the new regulations and technical information of JKN implementation to the implicated stakeholders include mini-monthly workshops, quarterly meetings, bulletin board notices and whatsapp group postings (WA). Information dissemination from PHCs to the community can be carried out through self-assessment surveys (SMD), village community meetings (MMD) and counselling and official letters.

The availability of communication media in conveying information about new regulations to policy holders, stakeholders, executors and targets for instance the Mayor of Denpasar, Denpasar Regional Secretary, BPJS Health Branch, Denpasar Health Office, and the community provides strong support for the implementation of communication contact.

The availability of media should be supported by adequate staff competence in the effective implementation of communication contacts. Employee motivation must be addressed and prioritised so that the performance of the implementer and the quality of service can be improved. ${ }^{16}$ The following quote is from an interview with one of the heads of a PHCs regarding the training and orientation of the implementing officer:

"...if their performance is deemed lacking, we capacitate them or hold a training workshop..." (Informant: K02).

The PHCs head conducts training and officer orientation for staff who do not have the necessary competencies. Competence and skills set if aligned to job/position would inevitably result in higher quality of service.

The implementation of communication contacts will support the improvement of service quality if accompanied by monitoring and evaluation. Regular feedback from BPJS to PHCs is one way to establish solid communication between BPJS and PHCs about effective service provision. Quality communication should be maintained so that implicated partners can negotiate with each other to find mutually beneficial understandings. This understanding can improve performance by finding a win-win situation. ${ }^{17}$

"...use of the application system and data systems are part of feedback indicator achievement..." (Informant: B01).

Feedback provided by BPJS should be effectively communicated so as to create a mutual understanding that leads to positive outcomes in the implementation of communication contacts.

\section{Enabling factors affecting the} implementation of contact communications Analysis of communications contacts practice indicates that the presence of strict supervision, the commitment of leaders and implementers is instrumental in achieving the target of communication contact as PHCs are vertical institutions managed 
under the Denpasar government. The policy set by the city government motivates staff to achieving the target of communication contact. The following are excerpts of interviews with heads of PHCs related to legitimacy and commitment.

"...I have mandatory monitoring reports I submit before the $7^{\text {th }}$ of every month..." (Informant: K03)

"...KBKP is dependent on commitment, above us is not just JKN but the City of Denpasar...nevertheless we still try as a vertically managed body to accommodate all mechanisms.." (Informant: K01).

PHCs are authorised to mobilise the community in identifying and solving health problems by cooperating with other sectors. ${ }^{7}$ PHCs in Denpasar city receive support from related parties in program implementation. The following is an excerpt from an interview with one of the heads of PHCs on cross-sectoral support.

\section{“...Cross sectoral support is immensely helpful but this often goes unrecognised and unrecorded...." (Informant: K01).}

Information disseminated both orally and in written form is one way of establishing effective communication on the implementation of communication contact activities.

Based on the findings in this study, researchers propose some corrective actions that should be considered by the central government, BPJS management, and Denpasar Health Office. The central government and BPJS could ensure optimal synergy in formulating policies so that the concept of the function of PHCs and the concept of capitation based on service commitment can be understood and implemented well. District health office should form a monitoring and evaluation team that specifically monitors the implementation indicators of service-based capitation commitments. PHCs as a work unit within the government can adopt the financial management pattern of regional public service agency (PPK BLUD) for more flexible financial management, prioritising effectiveness and efficiency as well as service quality.

\section{CONCLUSION}

Based on the results and discussions analysed, it can be concluded that inhibiting and enabling factors in the implementation of communication contacts are influenced by the regulation of communication contacts, resources and community participation. Easy-to-understand communication contact regulations, optimal availability of resources, understanding and community involvement in service delivery will inevitably result in effective communication contacts. One way to overcome the obstacles of achieving the target of communication contacts is remodeling of PHCs to function as independent units managed as regional public service agencies (PPK BLUD) so as to enable the implementation of a flexible and quality budget management system.

\section{ACKNOWLEDGEMENT}

We would like to convey thanks to all informants and all parties who supported the implementation and writing of this research. Special thanks to the Head of Denpasar Health Office who gave permission for the implementation of this research.

\section{REFERENCES}

1. Ministry of Health of Indonesia. Peraturan Menteri Kesehatan Republik Indonesia Nomor 28 tentang pedoman Program Jaminan Kesehatan Nasional [The Ministry of Health of Indonesia Regulation No. 28 on National Health Insurance Program]. Jakarta: Ministry of Health of Indonesia

2. Social Security Administering Agency. Peraturan Badan Penyelenggara Jaminan Sosial Kesehatan Nomor 2 Tahun 2015 tentang norma penetapan besaran kapitasi dan pembayaran kapitasi berbasis pemenuhan komitmen pelayanan pada fasilitas kesehatan tingkat pertama [Social Security Administering Agency Regulation No. 2 of 2015 on norms of setting capitation and capitation payments based on fulfillment of service commitments at primary health facilities]. Jakarta: Social Security Administering Agency; 2015.

3. Budiarto W, Kristiana L. Pemanfaatan dana kapitasi oleh fasilitas kesehatan tingkat pertama (FKTP) dalam penyelenggaraan JKN [The use capitation funds in the first level health facility (FKTP) the implementation JKN]. Buletin Penelitian Sistem Kesehatan. 2015; 18: 437-445.

4. Social Security Administering Agency Denpasar Branch. Laporan profiling indikator penilaian kinerja fasilitas kesehatan tingkat pertama [Profiling report of primary health facility performance indicators]. Denpasar: Social Security Administering Agency Denpasar Branch; 2016.

5. Ministry of Health of Indonesia. Peraturan Menteri Kesehatan Republik Indonesia Nomor 21 Tahun 2016 tentang Penggunaan Dana Kapitasi Jaminan Kesehatan Nasional Untuk Jasa Pelayanan Kesehatan dan Dukungan Biaya Operasional pada Fasilitas Tingkat Pertama [The Ministry of Health of Indonesia Regulation no. 21 of 2016 on Use of national health insurance capitation fund for healthcare services and support of operational costs at primary level facilities]. Jakarta: Ministry of Health of Indonesia; 2016.

6. Pradana GA. Diskresi dalam implementasi kebijakan publik di Puskesmas Kepanjen [Discretion in public policy implementation at Kepanjen Public Health Center]. Jurnal Ilmu Administrasi Publik. 2016; 2: 19-27.

7. Ministry of Health of Indonesia. Peraturan Menteri Kesehatan Republik Indonesia Nomor 75 Tahun 2014 tentang Pusat Kesehatan Masyarakat [The Ministry of Health of Indonesia Regulation no. 75 of 2014 on Public Health Center]. Ministry of Health of Indonesia; 2014. 
8. Social Security Administering Agency Denpasar Branch. Peraturan Bersama Sekretaris Jenderal Kementerian Kesehatan Republik Indonesia dan Direktur Utama Badan Penyelenggara Jaminan Sosial Kesehatan Nomor HK.02.05/III/SK /089/2016 Nomor 3 Tahun 2016 Tentang Petunjuk Teknis Pelaksanaan Pembayaran Kapitasi Berbasis Komitmen Pelayanan [Joint Regulation of the Secretary General of the Ministry of Health of Indonesia and the President Director of Social Security Administering Agency No. HK.02.05 / III / SK / 089/2016 No. 3 of 2016 on the Technical guidelines for the implementation of payment of commitment based capitation services]. Jakarta: Social Security Administering Agency Denpasar Branch; 2016.

9. Yandrizal, Anita B, Suryani D. Analisis kebijakan jaminan kesehatan Kota Bengkulu dalam upaya efisiensi dan efektifitas pelayanan di puskesmas [Policy analysis of Bengkulu City health insurance as an effort to improve efficiency and effectiveness of primary health centers]. Jurnal Kebijakan Kesehatan Indonesia. 2013; 2: 151-160.

10. Ministry of Health of Indonesia. Peraturan Menteri Kesehatan Republik Indonesia Nomor 71 Tahun 2013 tentang Pelayanan Kesehatan pada Jaminan Kesehatan Nasional [[The Ministry of Health of Indonesia Regulation No71 of 2013 on health care on national health insurance]. Jakarta: Ministry of Health of Indonesia; 2013.

11. Ministry of Home Affairs of Indonesia. Peraturan Menteri Dalam Negeri Nomor 61 Tahun 2007 tentang Pedoman Teknis Pengelolaan Keuangan Badan Layanan Umum Daerah [The Ministry of of Home Affairs of Indonesia Regulation No. 61 of 2007 on Technical guidelines for financial management of regional public service]. Jakarta: Ministry of Home Affairs of Indonesia; 2007.

12. Afandi MI, Warjio. Implementasi Peraturan Daerah Kabupaten Asahan Nomor 11 Tahun 2011 tentang pajak daerah dalam pencapaian target pajak bumi dan bangunan perdesaan dan perkotaan [Implementation regulation of Asahan Region number 11 in year 2011 on local taxes in achieving the target of property tax in rural and urban area]. Jurnal Administrasi Publik. 2015; 6: 93-113.
13. Mutiasari, Nur YM, Syamsul A. Implementasi kebijakan perizinan dan pemberitahuan kegiatan masyarakat pada Kepolisian Resort (Polres) Kota Kendari [The implementation of the licensing policies and notices of community activities in Kendari City Police]. e-Journal-Publica, PPS AP-UHO. 2016; 1(1): 1-14.

14. Yunevy EFT, Haksama S. Analisis kepuasan berdasarkan persepsi dan harapan pasien di Puskesmas Medokan Ayu Surabaya [Quality analysis based on perception and expectation of patients in Medokan Ayu Community Health Center Surabaya]. Jurnal Administrasi Kesehatan Indonesia. 2013; 1: 9-20.

15. Nurmansyah MI, Kilic B. The impact of national health insurance policy to the implementation of health promotion program on public health center in Indonesia. Kesmas National Public Health. 2017; 11: 103-110.

16. Nawawi M. Pengaruh motivasi dan kompetensi tenaga kesehatan terhadap kinerja pusat kesehatan masyarakat [Influence of motivation and competency of health personnel on the performance of public health center in Palu]. Mimbar. 2012; 28: 93-102.

17. Ramdhani M, Suryadi K. Consensus method development on analytic hierarchy process. ICOQSIA. 2005; 6-8.

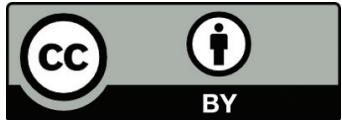

This work is licensed under a Creative Commons Attribution 